\title{
Assessing the Governance of Payment for Ecosystem Services in the Upper Catchments of the Lake Naivasha Basin
}

\author{
Jacob Kwamina Dodoo ${ }^{3}$, Robert M Kibugi' ${ }^{1 *}$ and Jesse T Njoka ${ }^{2 *}$ \\ ${ }^{1}$ School of Law, University of Nairobi, Parklands \\ ${ }^{2}$ Department of Land Resource Management and Agricultural Technology, University of Nairobi, Kenya \\ ${ }^{3}$ Wangari Maathai Institute for Peace and Environmental Studies, University of Nairobi, Kenya
}

Submission: August 28, 2018, Published: September 12, 2018

*Corresponding author: Robert M Kibugi, School of Law, University of Nairobi, Parklands. Email: rmkibugi@uonbi.ac.ke Jesse T Njoka, Department of Land Resource Management and Agricultural Technology, University of Nairobi, Kenya.

Email: jesse.njoka@uonbi.ac.ke; jtnjoka@gmail.com

\begin{abstract}
The importance of Water Resource Users Association (WRUA) committees is examined. Observed activities of the WRUA committees continue to enhance the efforts of members to engage in Payment for Ecosystem Services (PES) programs to meet its objectives. The success of some WRUA committees shows it can attain "win-win" outcomes in managing PES issues. The responses of 1143 PES farmers and 235 non-PES farmers interviewed were examined. Regression analysis were used to determine the significant association between the dependent variables, importance of WRUA committee and knowledge of negotiation process, water regulations and protected areas. The outcomes of these regression was synthesized to identify key factors that inform the formation of committees. Governance at the local level needs to be strengthened with streamlining the roles of each institution in addressing the water quality issue. The cooperation among all stakeholders was based on how they support the committees through capacity building, support through the provision of tree seedlings and awareness creation at the community levels. The results indicates the need for the government of Kenya to develop an expanded policy agenda on PES which will include WRUA committee formation. Also ensure the allocation of funds for institutional and management reorganization, for example WRUA committees are available.
\end{abstract}

Keywords: Ecosystem services; Farmers; Stakeholders; Committees

Abbreviations: WRUA: Water Resource Users Association; PES: Payment for Ecosystem Services; LNB: Lake Naivasha Basin; WWF: World Wide Fund for Nature

\section{Introduction}

Governance and institutions, as two concepts, are closely interlinked [1]. In Kenya, Naivasha, the concept of water governance has received increased attention [2]. The key question is whether 'institutions in the management of Payment for Ecosystem Services (PES) are effective enough to ensure the sustainability of the Lake Naivasha. A study conducted by [3], found that improved institutional arrangements have significant potential for an integrated ecosystem-based PES design. Therefore, good governance is promoted through transparency, accountability, and participation [4].

Kenya is a pioneer in implementing the concept of Payment for Ecosystem Services (PES) through a private scheme, which involved direct payments by service beneficiaries in this case the Lake Naivasha Water Resource Users Association (LANAWRUA), in the downstream catchment to service providers the Water Resource Users Association (WRUA) in the upper catchment of the Lake Naivasha Basin, in which both providers and beneficiaries are private entities (individuals, groups of individuals, private companies) with the government through the county participating only as an intermediary [5]. This paper aims at answering three questions: why PES was adopted, what are the factors resulting in the formation of WRUA committees, and how does the policy process affect the governance of the PES programme.

The governance and institutional arrangement supports the objective 3 of the PhD thesis in addressing the PES governance context regarding regulation set up for good governance and implementation as informed by Kenyan law and policy. According to [6], where enforcement of institutions is limited, there is the likelihood that rules will be disobeyed. This is the result of weak institutions [7]. Governance arrangements need to include civil society and private sector as well as government. A study by [8], argues that considering broad governance characteristics such as state capacity and legitimacy, the rule of law and political organization is essential in conflict-sensitive environments. The existing evidence base on governance instruments is weak in SubSaharan Africa [9].

In Africa, there is an emerging literature on river committees for example, Tanzania [10], the model of governance there is similar 
to that of Kenya, Naivasha, as it is based on the biophysical context and socio-economic context. For successful implementation and governance of PES schemes, it is essential to understand the various dimensions of value that can be shared by different groups within society about the natural environment [11].

In Kenya, Naivasha, the following institutions have been involved in the PES scheme. The LANAWRUA represents all stakeholders at the downstream catchments and the WRUA responsible for the upper catchment activities which includes onfarm soil and water conservation, rehabilitation, and management of riparian land, on-farm tree planting, rehabilitation of degraded sites, monitoring of silt loads in river water.

This study illustrated the implementation of positive governance of a PES scheme by understanding the emergence and functioning of river basin committees within the Lake Naivasha Basin. In the following, the key results followed by discussions and conclusions. This paper is part of my doctoral thesis.

\section{Materials and Methods}

\section{Study area}

The study was carried out in the upper catchments of the Lake Naivasha Basin (LNB). That is Wanjohi, Upper Turasha and Kiambogu catchment areas. Here WRUA committees are formed to address the needs of the LANAWRUA and ensure the efficient usage of the funds and also ensure the implementation of the contracts signed between the LANAWRUAs and the WRUAs. The main challenge to operationalizing WRUA committees is lack of clear legislation and undervaluation of ecosystem resulting to low resource allocation. The main institutions that have spearheaded the formation of the WRUA committees are the World-Wide Fund for Nature (WWF).

\section{Theoretical and empirical approach}

The study applied the Ostrom's design principles [10]. One of the eight design principles, monitoring, provided useful entry points in studying the functioning of the committees. As the knowledge of protected areas increases, farmers can make informed decisions on management practices to ensure a more sustainable approach to resource management. Nevertheless, as the knowledge of water regulations increases, farmers can make informed decisions on management practices to ensure a more sustainable approach to resource management. As there seems to be a high number of respondents who do not understand the negotiation process clearly, this would then affect the monitoring of the farmer's activity and its related sanctions.

In the context of PES, the study was interested in the degree to which powers have been devolved to institutions that are accountable to water resource users, as these are typically based on the failure of central government to deliver [12]. In this instance, powers refer to authority to make rules and decisions regarding water management, as well as to implement, enforce and adjudicate said rules. In practice, this implied attention to the degree to which the WRUAs can decide about the availability of water for abstraction, the issuance of permits, including decisions that affect the benefits that water use give rise to. This way of assessing what powers have been conferred on the lower level institutional arrangement is in line with the Kenya, Water Act, 2016. For any new water institution to be effective, it must be consistent with both the government and local-level institutions [10]. This, however, requires a good understanding of how local arrangements emerge, evolve and continue to function over time. Also, understanding the interface between locally developed water institutions and those created by the central government could add insight into the development of integrated catchment management institutions.

Accountability implies that the body receiving such powers can be held responsible, to answer for its actions, by members of the association living in the water catchment areas. Good governance is promoted through transparency, accountability and participation [4]. According to [13], trust is an ingredient in policymaking which concerns accountability mechanisms and capacity building. This goes to explain that trust is needed to be able to function effectively when dealing with water resource users. The study reviewed the Water Act 2016 and WRUA management plans and agreements (contract) and did in-depth interviews with key informants. These included:
a. 3 WRUA executives.
b. 1 WRA official.
c. $\quad 3 \mathrm{WWF}$ officials.
d. 2 Hoteliers

e. 1 Imarisha Naivasha official and 1378 farmers.

The informants were purposely selected for their ability to inform the study objectives. The interviews were guided by interview guides specific for each main stakeholder group prepared in advance of the interviews. Where the interviewee gave consent, the interviews were recorded, else detailed notes were taken.

Data analysis: The qualitative information gathered through interviews and informal discussions was transcribed and used to support the quantitative data. The quantitative data from the survey was organized in SPSS from where descriptive statistics and regression analysis were prepared to analyze the governance arrangement employed by stakeholders with different institutional needs.

A Likert scale (strongly agree to strongly disagree) was used to obtain information on trust from the PES farmers, as it is assumed that this measure would likely shape the governance-related outcomes. Before the survey, a list of governance indicators was defined based on focus group discussions with the stakeholders. During the survey, respondents were asked about Knowledge of 


\section{Agricultural Research \& Technology: Open Access Journal}

Protected Areas, Knowledge of Water regulation, Knowledge of Negotiation Process and Committee Importance.

The regression model was used to determine the relationship between the independent variables (Knowledge of Protected Areas, Knowledge of Water regulation, Knowledge of Negotiation Process and Committee Importance) and the dependent variable (perceived water quality after PES).

This paper is an important step to enhance governance capacities for the protected areas within the catchment areas by analyzing why they are important and how they might be integrated into coherent and effective protected area systems and offer practical guidance for stakeholders willing to embark on the process of assessing, evaluating and improving governance for a given system. Regarding the knowledge of water regulations, this paper addresses two main topics that will be key drivers for improved water governance in the near future. First, it discusses new practices of collaborative and disclosure of information for water governance for decision-making processes. Regarding knowledge of negotiation process LANAWRUA have established contractual agreements with WRUA, organised through WRUA committees, for land to be set aside as a 'conservancy' in exchange for payments to the community, based on annual fees or proportional payments (e.g., a percentage of gross or net revenues) and committee importance will try to establish whether their role is seen as important by the members.

Table 1: Adopted PES Practices.

\section{Results and Discussion}

Studies on the institutional arrangement of water governance have used a great variety of indicators such as accountability, trust and negotiation [14]. Trust is considered one of the key components for policy reform and is important in governance for several reasons. According to [13], trust decreases the risk inherent to cooperative relations since it creates greater predictability.

\section{Results}

Rate of payment for ecosystem services (PES) adoption rate by the non - PES farmers: The majority $(172,73.2 \%)$ of the non-PES farmers indicated that they had adopted PES practices. $(63,26.8 \%)$ of the non-PES farmers indicated that they had not adopted PES practices (Table 1). The majority $(642,46.6 \%)$ of the farmers indicated that the water quality after PES is average. The statement made by a KWS official stated this about the institutional arrangement which is coordinated by Imarisha Naivasha. The official stated that even though attempts are made on how these agencies can cooperate to achieve the objective of water quality, there seem to be some institutional challenges. However, there is some progress made with the intervention of Imarisha Naivasha, WRA in regulating water abstraction by the stakeholders (flower farmers, KenGen). Governance at the local level needs to be strengthened with streamlining the roles of each institution in addressing the water quality issue (Table 2).

\begin{tabular}{|c|c|c|}
\hline Adopted PES Practices & Frequency & Percent \\
\hline No & 63 & 26.8 \\
\hline Yes & 172 & 73.2 \\
\hline Total & 235 & 100 \\
\hline
\end{tabular}

Table 2: Water Quality after PES.

\begin{tabular}{|c|c|c|}
\hline \multicolumn{2}{|c|}{ Water Quality After } \\
\hline & N & \multicolumn{2}{c|}{ Percent } \\
\hline Poor & 117 & 46.5 \\
\hline Average & 642 & 44.9 \\
\hline Good & 619 & 100 \\
\hline Total & 1378 & \\
\hline
\end{tabular}

Assessing the importance of WRUA committees: In knowledge of negotiation process was regressed against the assessing the governance of PES, using water quality as a dependent variable, the study used a binomial logistic regression model, because the outcome variable was measured as a dichotomous (Yes/No). Regression analysis was chosen to analyse the independent variables: knowledge of water regulations; knowledge of Protected Areas; the committee importance; dependent variables water quality. The regression analysis was used to test the nature of relationships between the dependent variables and the independent variables (Table 3). The model produced a Nagelkerke value of $22 \%$. This implies the independent variables were explaining $22 \%$ of the variation in the dependent variable (Water quality after PES).

Table 3: Regression on committee.

\begin{tabular}{|c|c|c|c|c|c|c|}
\hline Average & \multicolumn{3}{|c|}{ Average } & & Good \\
\hline & B & P-Value & OR [95\% CI] & B & Palue & OR [95\% CI] \\
\hline Constant & -0.06 & 0.93 & & 0.58 & & \\
\hline $\begin{array}{c}\text { Protected } \\
\text { Area }\end{array}$ & & & & & & \\
\hline No & 2.21 & $<0.001$ & $\begin{array}{l}9.08[3.41, \\
24.17]\end{array}$ & 2.41 & $<0.001$ & $\begin{array}{c}11.15[4.26, \\
29.22]\end{array}$ \\
\hline
\end{tabular}


Agricultural Research \& Technology: Open Access Journal

\begin{tabular}{|c|c|c|c|c|c|c|}
\hline Yes (RC) & & & 1 & & & 1 \\
\hline \multicolumn{7}{|l|}{$\begin{array}{r}\text { Water } \\
\text { Regulation }\end{array}$} \\
\hline High & 0.87 & 0.068 & $\begin{array}{l}2.380 .94, \\
6.02]\end{array}$ & 0.45 & 0.339 & $\begin{array}{l}1.57[0.62, \\
3.98]\end{array}$ \\
\hline Medium & 1.29 & $<0.001$ & $\begin{array}{l}3.65[1.95, \\
6.82]\end{array}$ & 1.06 & 0.001 & $\begin{array}{l}2.88[1.56, \\
5.32]\end{array}$ \\
\hline Low (RC) & & & 1 & & & 1 \\
\hline \multicolumn{7}{|l|}{$\begin{array}{r}\text { Process } \\
\text { Negotiations }\end{array}$} \\
\hline $\begin{array}{r}\text { Strong } \\
\text { knowledge }\end{array}$ & 0.45 & 0.349 & $\begin{array}{l}1.57[0.61, \\
4.05]\end{array}$ & 0.11 & 0.813 & $\begin{array}{l}1.12[0.43, \\
2.91]\end{array}$ \\
\hline $\begin{array}{c}\text { Fair } \\
\text { knowledge }\end{array}$ & -0.63 & $<0.001$ & $\begin{array}{l}0.53[0.27, \\
1.05]\end{array}$ & -0.01 & 0.985 & $\begin{array}{l}0.99 \text { [ } 0.51, \\
1.93]\end{array}$ \\
\hline Neutral (RC) & & & 1 & & & 1 \\
\hline \multicolumn{7}{|l|}{$\begin{array}{l}\text { Committee } \\
\text { Important }\end{array}$} \\
\hline Agree & 2.42 & 0.001 & $\begin{array}{l}11.19[2.61, \\
47.93]\end{array}$ & 1.55 & 0.026 & $\begin{array}{l}4.72[1.2, \\
18.57]\end{array}$ \\
\hline Neutral & -0.52 & $<0.001$ & $\begin{array}{l}0.59[0.14 \\
2.47]\end{array}$ & -0.76 & $<0.001$ & $\begin{array}{l}0.47[0.12, \\
1.77]\end{array}$ \\
\hline Disagree (RC) & & & 1 & & & 1 \\
\hline \multicolumn{7}{|l|}{ Source } \\
\hline $\begin{array}{l}\text { Nagelkerke } \\
\text { R-Square }\end{array}$ & 0.221 & & & & & \\
\hline $\begin{array}{l}\text { Reference } \\
\text { Category }\end{array}$ & $\mathrm{RC}$ & & & & & \\
\hline Odds Ratio & OR & & & & & \\
\hline $\begin{array}{c}\text { Reference } \\
\text { Category is Poor }\end{array}$ & & & & & & \\
\hline
\end{tabular}

Knowledge of protected areas: There was a significant association between Knowledge of Protected Area and Water quality after PES. Farmers who do not have knowledge of Protected Area were 9.08 times as likely to rate the water quality as Average than Poor as compared to farmers with knowledge of

Protected Legislation Area. They were also 11.15 times as likely to rate the water quality as Good than Poor when compared with farmers in with knowledge of protected areas (Table 4). Majority of the farmers $(1128,81.9 \%)$ had knowledge of protected areas.

Table 4: Knowledge of Protected Areas.

\begin{tabular}{|c|c|c|}
\hline \multicolumn{2}{|c|}{ Knowledge of Protected Area } & Percent \\
\hline & N & 18.1 \\
\hline No & 250 & 81.9 \\
\hline Yes & 1128 & 100 \\
\hline Total & 1378 & \\
\hline
\end{tabular}

Knowledge of water regulations: A farmer with Medium knowledge of water regulation was 3.65 times as likely to rate the water quality as Average than Poor as compared to farmers with low knowledge of water regulation. They were also 2.88 times as likely to rate the water Quality as Good than Poor. There was no significant association between High knowledge of water regulation and Water quality rating. Nevertheless, Farmers with high knowledge of water regulation were 2.38 times as likely to rate the water quality as Average than Poor as compared to farmers with Low knowledge of water regulation. They are also 1.57 times as likely to rate the water quality as Good than Poor (Table 5). Majority of the farmers had a general idea of water regulation. 
Table 5: Knowledge of Water Regulation.

\begin{tabular}{|c|c|c|}
\hline \multicolumn{3}{|c|}{ Water Regulation } \\
\hline & N & Percent \\
\hline High & 178 & 12.9 \\
\hline Medium & 694 & 50.4 \\
\hline Low & 506 & 36.7 \\
\hline Total & 1378 & 100 \\
\hline
\end{tabular}

Table 6: Importance of Committee.

\begin{tabular}{|c|c|c|}
\hline \multicolumn{3}{|c|}{ Importance of Committee } \\
\hline & $\mathbf{N}$ & Percent \\
\hline Agree & 846 & 74 \\
\hline Neutral & 270 & 23.6 \\
\hline Disagree & 27 & 2.4 \\
\hline Total & 1143 & 100 \\
\hline
\end{tabular}

Importance of WRUA committees: There was a strong significant association between Committee Importance and Water quality after PES. Hence, the higher the number of farmers who agree to the importance of committees, the higher the number of farmers who will rate the water quality as good as they will monitor water usage and any activities within the LNB to ensure compliance and adhering to the necessary Memorandum of Understanding (MoU) and rules (Table 6). There was a strong significant association between Committee Importance and Water quality after PES. Majority of the farmers $(846,74 \%)$ agreed that committees are important.

Knowledge of negotiation process: In the negotiation process, the upper catchment farmers are to engage in sustainable farm practices to ensure water quality. This arrangement is stipulated in the contract. However, there seems to be a high number of the respondent who seems not to understand the process. This would then affect the monitoring of the farmer's activity and its related sanctions (Table 7). Majority of the farmers don't have knowledge in negotiation process.

Table 7: Knowledge of Negotiation Process.

\begin{tabular}{|c|c|c|}
\hline \multicolumn{3}{|c|}{ Knowledge of Process Negotiations } \\
\hline & $\mathbf{N}$ & Percent \\
\hline Strong knowledge & 238 & 20.8 \\
\hline Fair knowledge & 375 & 32.8 \\
\hline No & 530 & 46.4 \\
\hline Total & 1143 & 100 \\
\hline
\end{tabular}

\section{Discussion}

\section{On the role of committees in monitoring}

This section discusses the committee formation and assesses the emergence of these institutions. From the literature review, rules, monitoring and enforcement at the local level [15], can be identified as contributory factors for the committee formed in the LNB catchments. Billboards were placed in rivers around the tributaries of Wanjohi and Turasha. The WRUA member who are gauge readers are able to monitor the status of their respective rivers and adjust the billboards accordingly. Because it was realized that the WRUAs are weak in Governance and Financial issues. It was agreed that the WRUAs be capacity build in areas that they are weak.

Governance at the local level needs to be strengthened with streamlining the roles of each institution in addressing the water quality issue. The cooperation among all stakeholders was based on how they support the committees through capacity building, support through the provision of tree seedlings and awareness creation at the community levels. Other support came from recruiting staff from communities as part of their drive to ensure increased livelihood.

Attempts at implementing PES in Africa has not reached the expected targets, both in reducing poverty and strengthening social justice, because of numerous pitfalls to effective policy design. Hence, there is the need to design policy and institutional arrangements around PES programs [16]. According to [17], different legal and regulatory frameworks are required for different types of payment schemes. Hence, the need for different policies when externalities are occurring together [18].

The WRUA committees have benefited from the already existing arrangements such as WRA, WRUA and civil societies. The Water Act 2016 highlights the role of county government. However, a study in Kenya, undertaken by [19], investigated the influence of decision-making at local, regional or national level. The results suggest that decision making on ecosystem services in Africa are not homogenously distributed [19]. Hence the need to strengthen decision making at all levels through local committees, regional and national bodies.

In the negotiation process, the upper catchment farmers are to engage in sustainable farm practices to ensure water quality. This arrangement is stipulated in the contract. However, there seems to be a high number of the respondent who seems not to understand the process. This would then affect the monitoring of the farmer's activity and its related sanctions [20-23].

\section{Conclusion}

This chapter discussed the importance of WRUA committees. Ostrom's design principles provided useful entry points in studying the functioning of the committees. One of the eight design principles was used to examine the governance of PES, which is, monitoring. The growing popularity of PES programs as an environmental conservation and poverty alleviation instrument warrants scrutiny of its potential. In this paper, I attempted to identify those factors that influence the formation of WRUA committee. I conducted a quantitative binary logistic regression and qualitative literature analysis to meet this objective.

Statistically significant coefficients suggest that formation of committees is essential to achieve environmental conservation 
and "win-win" outcomes. Similarly, capacity building for WRUA members in managing and monitoring water uses must sufficiently cover the transaction and/or opportunity costs of enrolling and engaging someone from WRA. Additionally, we find a number of WRUA members who are not clear with the contracts negotiated as identified from the field reviews. Our qualitative analysis shows challenges faced by the WRUA committees in addressing their administrative duties due to lack of office equipment and support, primarily funding. The qualitative analysis also revealed that the most effective activity the committee has established is the common intake at the rivers/water points and the demolition of illegal abstractors. All these factors are effective when they solve local challenges and efficiently minimize costs. The WRUA committee can benefit from government participation by exploiting economies of scale enjoyed by government agencies to manage high transaction and operating costs. The overarching task for WRUA committee is active engagements with WRA to recognize their needs and design the program accordingly.

Given the lack of capacity of WRA to manage water resources, NGOs (WWF and German Technical Cooperation Agency (GTZ)) are helping build capacity to address the issue of governance through the devolved roles of the national government to the counties as stipulated in the Water Act 2016. It is also recommended that the government of Kenya develop an expanded policy agenda on PES which will include issuing of title deeds, methods of cooperation and WRUA committee formation. In line with the Water Act 2016, the government of Kenya will need to create a national policy agenda on PES, which would include: the prioritization of agricultural extension services as part of a national multi-sectoral integrated water resource management network; and the allocation of funds for institutional and management reorganization (for example WRUA committees). The national policy agenda to be developed on PES will then hope to achieve the effectiveness of PES through cooperation among the relevant sectors to develop programmes for PES to achieve improved water quality and conflict reduction.

\section{References}

1. McFadden L, Priest, S, Green C (2010) Introducing institutional mapping: A guide for SPICOSA scientists. Spicosa Project, Flood Hazard Research Centre, London, UK, pp. 1-17.

2. Lemoine N, Patrick RJ (2014) Water Governance in Northern Saskatchewan: Opportunities and Challenges. CJUR 23(1): 46-60.

3. Lin H, Nakamura M (2012) Payments for watershed services: Directing incentives for improving lake basin governance. Lakes \& Reservoirs: Research and Management 17(3): 191-206.

4. Bennett NJ, Dearden P (2014) Why local people do not support conservation: Community perceptions of marine protected area livelihood impacts, governance and management in Thailand. Marine Policy 44: 107-116.

5. Greiber T (2011) Enabling conditions and complementary legislative tools for PES, in Payment for ecosystem services and food security, Food and Agriculture Organization of the United Nations, pp. 205-225.
6. Agrawal (2003) Sustainable Governance of Common-Pool Resources: Context, Methods, and Politics. Home Annual Review of Anthropology 32: 243-262.

7. Zhu X, Clements R, Haggar J, Quezada A, Torres J (2001) Technologies for Climate Change Adaptation - Agriculture Sector. Roskilde: Danmarks Tekniske Universitet, Risø Nationallaboratoriet for Bæredygtig Energi. p. 299.

8. Ratner BD, Cohen P, Barman B, Mam K, Nagoli J, et al. (2013) Governance of Aquatic Agricultural Systems: Analyzing Representation, Power, and Accountability. Ecology and Society 18(4): 59.

9. Schoneveld GC (2013) The Governance of Large-Scale Farmland Investments in Sub-Saharan Africa: A Comparative Analysis of the Challenges for Sustainability. Eburon Delft, Netherlands, p. 318.

10. Komakech HC, van der Zaag P (2011) Understanding the Emergence and Functioning of River Committees in a Catchment of the Pangani Basin, Tanzania. Water Alternatives 4(2): 197-222.

11. Reed MS, Allen K, Attlee A, Dougill AJ, Evans KL, et al. (2017) A place-based approach to payments for ecosystem services. Global Environmental Change 43: 92-106.

12. Kauzya JM (2007) Political Decentralization in Africa: Experiences of Uganda, Rwanda, and South Africa.

13. Cerna L (2014) Trust: What it is and Why it Matters for Governance and Education. OECD Education Working Papers. No. 108, OECD Publishing, p. 66.

14. Kovacs EK, Kumar C, Agarwal C, Adams WM, Hope RA, et al. (2016) The politics of negotiation and implementation: a reciprocal water access agreement in the Himalayan foothills, India. Ecology and Society 21(2): 37.

15. Engel S, Pagiola S, Wunder S (2008) Designing payments for environmental services in theory and practice: An overview of the issues. Ecological Economics 65(4): 663-674.

16. Andrew AG, Masozera (2010) Payment for Ecosystem Services and Poverty Reduction in Rwanda. Journal of Sustainable Development in Africa 12(3): 129-139.

17. Sara Scherr, Andy White, Arvind Khare (2004) The Current Status and Future Potential of Markets for the Ecosystem Services Provided by Tropical Forests. For Services Rendered p. 74.

18. Ezzine-de-Blas, Sven Wunder, Manuel Ruiz-Pérez, Rocio del Pilar Moreno-Sanchez (2016) Global Patterns in the Implementation of Payments for Environmental Services. Plos One.

19. Wangai PW, Burkhard B, Müller F (2016) A review of studies on ecosystem services in Africa. International Journal of Sustainable Built Environment 5(2): 225-245.

20. Downard R, Endter-Wada J, Kettenring KM (2014) Adaptive wetland management in an uncertain and changing arid environment. Resilience Alliance 19(2): 23.

21. Fauzi A, Anna Z (2013) The complexity of the institution of payment for environmental services: A case study of two Indonesian PES schemes. Ecosystem Services 6: 54-63.

22. Turner RA, Addison J, Arias A, Bergseth BJ, Marshall NA, et al. (2016) Trust, confidence, and equity affect the legitimacy of natural resource governance. Ecology and Society 21(3): 18.

23. Wertz-Kanounnikoff S, Locatelli B, Wunder S, Brockhaus M (2011) Ecosystem-based adaptation to climate change: what scope for payments for environmental services? Climate and Development 3(2): 143-158. 
This work is licensed under Creative Commons Attribution 4.0 License

DOI:10.19080/ARTOAJ.2018.17.556034
Your next submission with Juniper Publishers will reach you the below assets

- Quality Editorial service

- Swift Peer Review

- Reprints availability

- E-prints Service

- Manuscript Podcast for convenient understanding

- Global attainment for your research

- Manuscript accessibility in different formats ( Pdf, E-pub, Full Text, Audio)

- Unceasing customer service

Track the below URL for one-step submission https://juniperpublishers.com/online-submission.php 